\title{
Heavy Metals in Marsh Clam (Polymesoda expansa) as Bioindicators for Pollution in Industrial and Sand Mining Area of Kelantan River Basin, Malaysia
}

\author{
Abdul Hafidz Yusoff ${ }^{1, *}$, Nurul Nashuha Roslan ${ }^{1}$, Chang Shen Chang ${ }^{1}$, \\ Azwan Mat Lazim², Mohd Shahrul Mohd Nadzir², Siti Nur Hazwani Oslan³, \\ Ahmad Ziad Sulaiman ${ }^{1}$, Minhaz Farid Ahmed ${ }^{4}$, Mazlan Mohamed, \\ Khairul Anam Zakaria ${ }^{5}$ and Reasmey Tan ${ }^{6}$
}

\author{
${ }^{1}$ Gold Rare Earth and Material Technopreneurship Centre (GREAT), Faculty of Bioengineering and \\ Technology, Universiti Malaysia Kelantan, Jeli Campus, 17600 Jeli, Kelantan, Malaysia \\ ${ }^{2}$ Faculty of Science and Technology, Universiti Kebangsaan Malaysia, 43600 Bangi Selangor, Malaysia \\ ${ }^{3}$ Faculty of Food Science and Nutrition, Universiti Malaysia Sabah, Jalan UMS, Kota Kinabalu, 88400 , \\ Sabah, Malaysia \\ ${ }^{4}$ Institute for Environment and Development (LESTARI), Universiti Kebangsaan Malaysia, 43600 Bangi \\ Selangor, Malaysia \\ ${ }^{5}$ World Aquatic Resources Sdn Bhd, Kampung Batang Merbau, 17500 Tanah Merah, Kelantan, Malaysia \\ ${ }^{6}$ Research and Innovation Center, Institute of Technology of Cambodia, 12156 Phnom Penh, Cambodia
}

("Corresponding author's e-mail: hafidz.y@umk.edu.my)

Received: 7 May 2020, Revised: 27 May 2021, Accepted: 31 May 2021

\begin{abstract}
Industrial and sand mining activities have severely degraded the water quality of the Kelantan River, as well as the river ecosystem. However, there have been inadequate studies on the effect of industrial and sand mining on organisms in the Kelantan River. Therefore, this study assessed the concentrations of $\mathrm{Pb}, \mathrm{Cd}, \mathrm{Zn}$ and $\mathrm{Cu}$ in the bivalves of genus (Polymesoda expansa) marsh clams from the Kelantan River tributaries, namely the Geting River and the Semarak River, which are located near to an industrial and a sand mining area, respectively. More than 50 marsh clams were collected at these sites. Heavy metals in marsh clams were extracted using aqua regia methods and analyzed using a Flame Atomic Absorption Spectrometer (FAAS). The mean concentrations of $\mathrm{Pb}, \mathrm{Cd}, \mathrm{Zn}$ and $\mathrm{Cu}$ at the Semarak River were 4.61, 2.16, 194 and $6.20 \mathrm{mg} / \mathrm{kg}$, respectively. Accordingly, the concentrations at the Geting River were 4.43, 2.50, 196 and $7.90 \mathrm{mg} / \mathrm{kg}$, respectively. The pattern of metal concentrations within the whole tissue of marsh clams from the Geting River and the Semarak River were in the following order: $\mathrm{Zn}>\mathrm{Cu}>\mathrm{Pb}>\mathrm{Cd}$ (concentration in $\mathrm{mg} / \mathrm{kg}$ ). The mean concentration of selected metals $(\mathrm{Zn}, \mathrm{Cd}, \mathrm{Pb})$ in the studied samples exceeded the permissible limit set by the Malaysia Food Safety and Food Regulation 1985, the Food and Agricultural Organization, the World Health Organization, the Ministry of Health Thailand, and the Food and Drug Administration of United States (USFDA). Therefore, continuous monitoring of these bioindicators is essential to minimize the increasing health risk for aquatic life, as well as in food sources for human consumption, in the Kelantan River Basin.
\end{abstract}

Keywords: Marsh clams, Bioaccumulation, Heavy metals, Aquatic environment, Kelantan River

\section{Introduction}

Malaysia is a Southeast Asian country with high socioeconomic development. In recent years, the water environment in most areas of Malaysia has suffered a certain level of various types of pollution [1-3]. The Kelantan River, which is the major river in Peninsular Malaysia, has shown increasing levels of heavy metal pollution in recent years [4]. The Kelantan River has been profoundly affected by anthropogenic activities such as industrialization, agricultural practice and the discharging of domestic sewage. Sand mining in the Kelantan River has constantly degraded the river bed and has caused waterway siltation, thus deteriorating water quality, which has greatly depleted the fish and benthic organism populations [5]. Contamination of the river with various kinds of pollutants enriched with heavy metals caused by sand mining might be the main reason of these local biodiversity shifts. A small amount 
of essential metals like $\mathrm{Fe}, \mathrm{Mn}, \mathrm{Cu}$ and $\mathrm{Zn}$ are vital to most living organisms for their growth [6,7] but will have a deleterious impact when concentrations of these metal pass the standard limits [8]. Excessive consumption of bivalves which have been bio-accumulated with nonessential metals such as $\mathrm{Cd}, \mathrm{As}, \mathrm{Hg}$, $\mathrm{Pb}, \mathrm{Ni}$ and $\mathrm{Cr}$, which are toxic to organisms even at low concentrations, may imperil human health $[9,10]$.

Bivalves are well known as filter feeders for suspended particles within water columns that may be contaminated with numerous contaminants including heavy metals obtained from either anthropogenic activities or natural emissions; this is becoming a source of heavy metal uptake in their bodies [11]. They tend to concentrate contaminants at a much higher level than the natural background concentrations in the environment [12]. Therefore, they are the most suitable bioindicators to observe heavy metal pollution in the aquatic ecosystem [13]. Marsh clams have been previously used as biomonitors to examine the ecological condition of a marine habitat [14].

The accumulated heavy metals in marsh clams can reach humans via the food chain and chronic illnesses probably can be induced in humans when these metal-polluted marsh clams are consumed. Therefore, it is crucial to determine the concentrations of heavy metals in marsh clams to assess the potential human health risks of marsh clam consumption. The permissible limits of each heavy metal in food have been set by the Malaysia Food Safety and Food Regulation 1985, the Food and Agricultural Organization, the World Health Organization, the Ministry of Health Thailand and the Food and Drug Administration of United States (USFDA) in order to determine whether marsh clams are edible. Hence, this study was conducted to evaluate the contamination levels of heavy metals in the Kelantan River using Polymesoda expansa as a bioindicator for 4 heavy metals $(\mathrm{Cu}, \mathrm{Zn}, \mathrm{Cd}$ and $\mathrm{Pb})$.

This study provides necessary data for further research to monitor the levels of heavy metals in marsh clams in the Kelantan River tributaries, namely the Geting River and the Semarak River, which are located near to an industrial and a sand mining area, respectively. The information obtained from this study is new knowledge and is a preliminary study for the local and international scientific community. This new knowledge has contributed in terms of providing some useful detailed information about the level of contamination in the rivers around Kelantan, especially near to a sand mining area in Kelantan. Additionally, the information gained from this study might benefit policymakers when making judgments. Government agencies, for example, the Ministry of Health Malaysia, might use the data to calculate the health risks to humans of consuming marsh clams, as well as to suggest the consumption limits for marsh clams that are of high risk.

\section{Materials and methods}

\section{Sample collection}

Marsh clams in the range of $54-80.9 \mathrm{~mm}$ were collected in January - March 2018 from the mangrove area of the Geting River, which is close to the Tumpat industrial area near Kampung Geting in Kelantan at the coordinates E $102^{\circ} 06^{\prime} 22.248{\mathrm{~N} 06^{\circ}}^{\circ} 13^{\prime} 35.893$. Similarly, in Tok Bali Pasir Puteh, marsh clams were collected near to a sand mining area at the Semarak River, coordinates E $102^{\circ} 30^{\prime} 44.635 \mathrm{~N} 5^{\circ}$ 51'48.079. Both sampling locations of marsh clams are shown in Figure 1.

\section{Sample preparation}

The collected samples were stored in a laboratory refrigerator. The samples were divided into 3 different sizes, at ranges of $40-55,56-75$ and $76-90 \mathrm{~mm}$. Clams get bigger as they get older. However, we could not predict the clams age based on size only. The edible parts of the samples were weighed, followed by undergoing a drying process. The dried samples were weighed and grounded into powder using a pestle and mortar. The homogenate samples were divided into 3 subsamples for the analyses of replicates. After preparation, the homogenate samples were stored at $20{ }^{\circ} \mathrm{C}$ in polypropylene containers until further analysis [15]. 

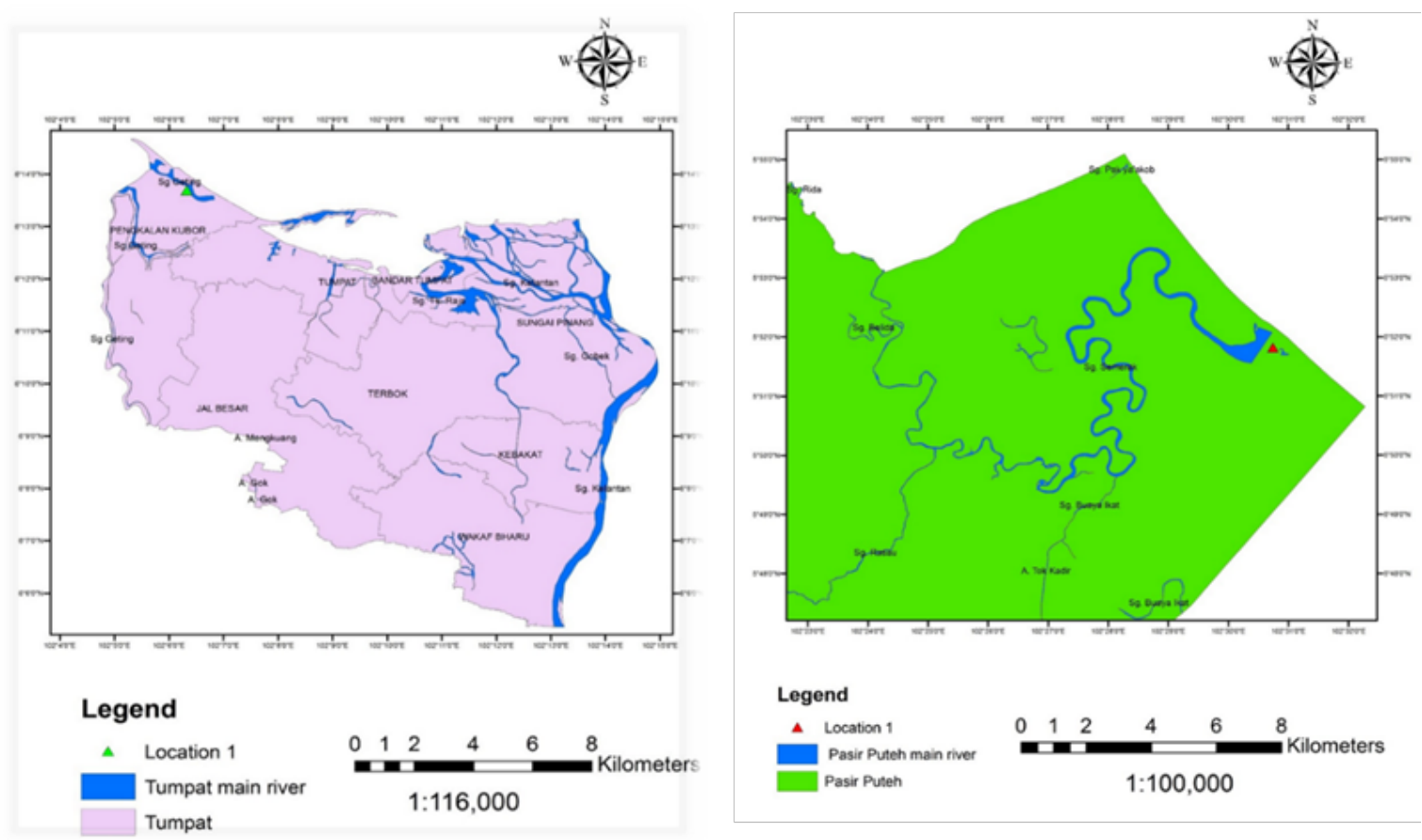

Figure 1 Locations of the Geting River, Tumpat Kelantan and the Semarak River, Pasir Puteh Kelantan, which are located near to an industrial and a sand mining area, respectively.

\section{Analytical method}

The homogenate samples were weighed into sizes of $2.5 \mathrm{~g}$ in petri dish. The analytical method involved an aqua regia digestion procedure consisting of digesting the samples on a hot plate with a mixture of $\mathrm{HCL}$ and $\mathrm{HNO}_{3}$, as prescribed by Kmaruzzaman et al. [6] and Ebadi et al. [16]. The nitric acid reacted with concentrated $\mathrm{HCl}$ to form aqua regia; $3 \mathrm{HCl}+\mathrm{HNO} 3 \rightarrow 2 \mathrm{H}_{2} \mathrm{O}+\mathrm{NOCL}+\mathrm{Cl}_{2}$. After filtration, the samples were prepared for determination of $\mathrm{Cd}, \mathrm{Cu}, \mathrm{Pb}$ and $\mathrm{Zn}$ by using a Flame Atomic Absorption Spectrometer (F-AAS), model PinAAcle900f Perkin Elmer, with detection limits for $\mathrm{Zn}, \mathrm{Pb}$,

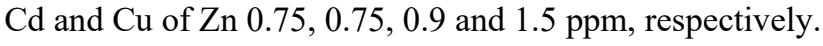

\section{Result and Discussion}

\section{Heavy metals in marsh clams}

The average concentrations of $\mathrm{Cu}, \mathrm{Zn}, \mathrm{Pb}$ and $\mathrm{Cd}$ in the tissue of marsh clams of both study areas, which were the Getting River and the Semarak River, are presented in Figure 2. The average concentrations of these metals were found in the following ranking: $\mathrm{Zn}>\mathrm{Cu}>\mathrm{Pb}>\mathrm{Cd}$. The metal levels in the marsh clam tissue of both places gave a similar ranking. The highest concentration was Zinc (Zn) and the lowest was Cadmium $(\mathrm{Cd})$.

Based on Figure 2, the concentration of zinc $(\mathrm{Zn})$ in the Geting River at Tumpat and the Semarak River at Tok Bali was significantly higher at $194 \pm 0.09$ and $196 \pm 0.16 \mathrm{mg} / \mathrm{kg}$, respectively. The Semarak River at Tok Bali showed the highest value of $\mathrm{Zn}$ concentration compared to the Geting River at Tumpat Kelantan, which might have been due to high mining activities, shipping, and fishing boat activities. $\mathrm{Zn}$ is an essential element for humans, but a deficiency, as well as an excess of its consumption by humans is harmful. $\mathrm{Zn}$ was found to be the highest concentration in aquatic organisms because zinc is extremely important for the immune system in organism bodies [17]. 


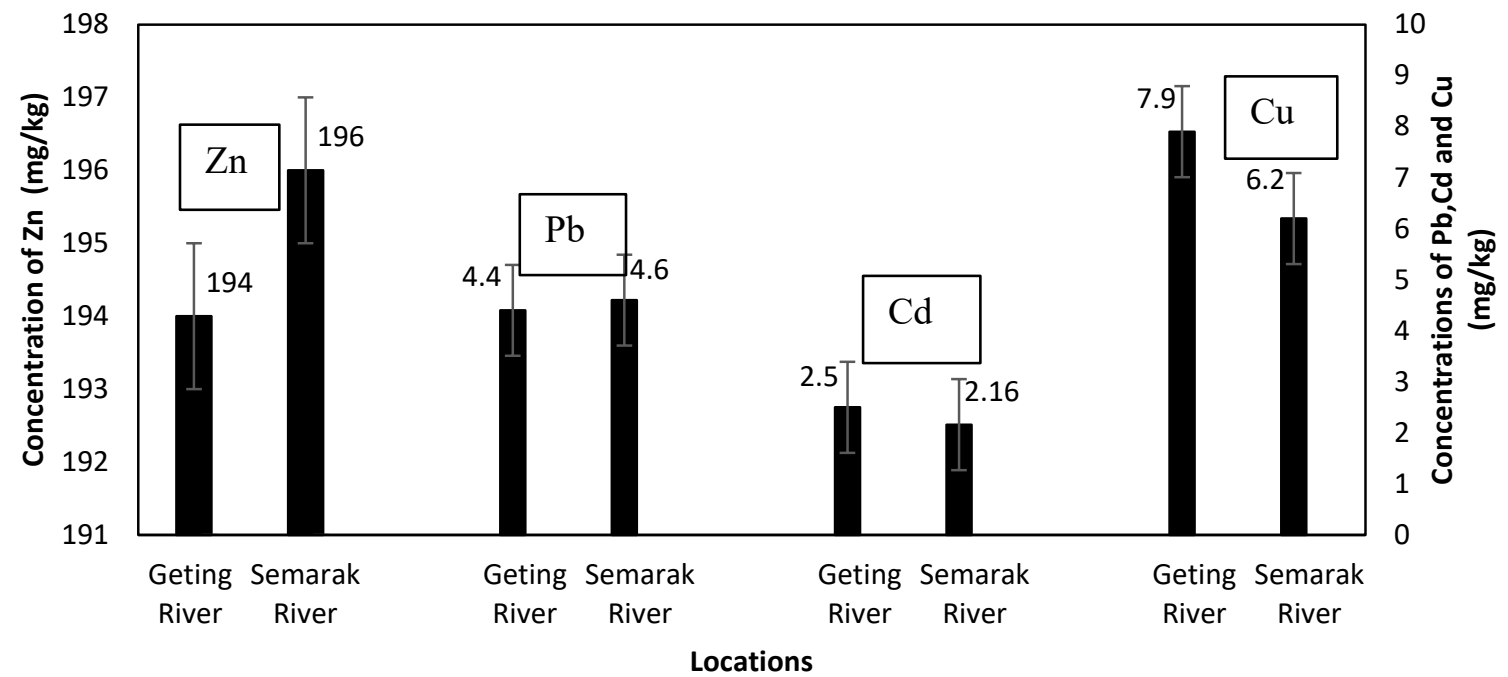

Figure 2 Concentrations of heavy metals $(\mathrm{Zn}, \mathrm{Pb}, \mathrm{Cd}$ and $\mathrm{Cu})$ in Marsh Clams from the Geting River and the Semarak River, Kelantan.

Concentrations of lead $(\mathrm{Pb})$ were detected in all marsh clams of both places. The average concentrations of lead in this species were $4.4 \pm 0.01$ and $4.6 \pm 0.02 \mathrm{mg} / \mathrm{kg}$ at the Genting River and the Semarak River, respectively. These metals are toxic and are not metabolized in clams. Therefore, these metals are easily excreted from the flesh. Lead is a cumulative toxic trace metal and is one of the environmental contaminants which can promote serious damage to human health through damaging blood circulation, the central nervous system, the liver, and the kidneys [18,19].

Moreover, the concentrations of cadmium $(\mathrm{Cd})$ in the marsh clams at the Semarak River and the Geting River were 2.2 and $2.5 \mathrm{mg} / \mathrm{kg}$, respectively. Cd is an essential component for the manufacture of batteries, anti-corrosive coatings of metals and bearing alloys. Other studies have also found higher concentrations of heavy metals, i.e., $\mathrm{Cd}$, in selected fish samples from the Kelantan River which were above the permitted levels set by regulations [20]. The concentrations of $\mathrm{Cd}$ in fish tissue from the Kelantan River were $0.076 \mathrm{mg} / \mathrm{kg}$, as reported by Hashim et al. [20], lower than the value of Cd in marsh clams from this study. Concentrations of $\mathrm{Cd}$ in marsh clams were higher compared to those in fish because clams live in sediment, while fish live in water. Concentrations of heavy metals in sediment are higher compared to River water because sediment acts as an ultimate sink for inorganic and organic compounds including heavy metals, aliphatic hydrocarbons, and polycyclic aromatic hydrocarbons $[1,3]$.

The concentrations of Copper $(\mathrm{Cu})$ in the soft tissue of marsh clams were determined to be $7.9 \pm$ $0.04 \mathrm{mg} / \mathrm{kg}$ from 2 different places at the Geting River, Tumpat Kelantan. However, in the Semarak River, the concentration of $\mathrm{Cu}$ was comparatively lower, at $6.2 \mathrm{mg} / \mathrm{kg} \pm 0.05$, than the Getting River. The higher level of $\mathrm{Cu}$ might function as a biocide which is responsible for the protection of biofouling in marine vessels [21]. Copper is an essential trace metal for living organisms due to its vital role in allowing many critical enzymes to function properly [22].

\section{Effects of size on the concentrations of heavy metals}

Figure 3 show the sizes of marsh clams and the concentrations of heavy metals. Generally, the smaller size of marsh clams had higher metal concentrations than the bigger and medium sizes. For example, the concentrations of $\mathrm{Cu}$ in the Semarak River determined that the smaller size of marsh clams had higher concentrations than the medium and larger sizes of marsh clams. In addition, bioaccumulation of $\mathrm{Cd}$ was higher in the medium size, $\mathrm{Cu}$ was higher in the smaller size, and $\mathrm{Pb}$ was found in higher concentrations in the small size of marsh clams, indicating no consistency in bioaccumulation patterns. 

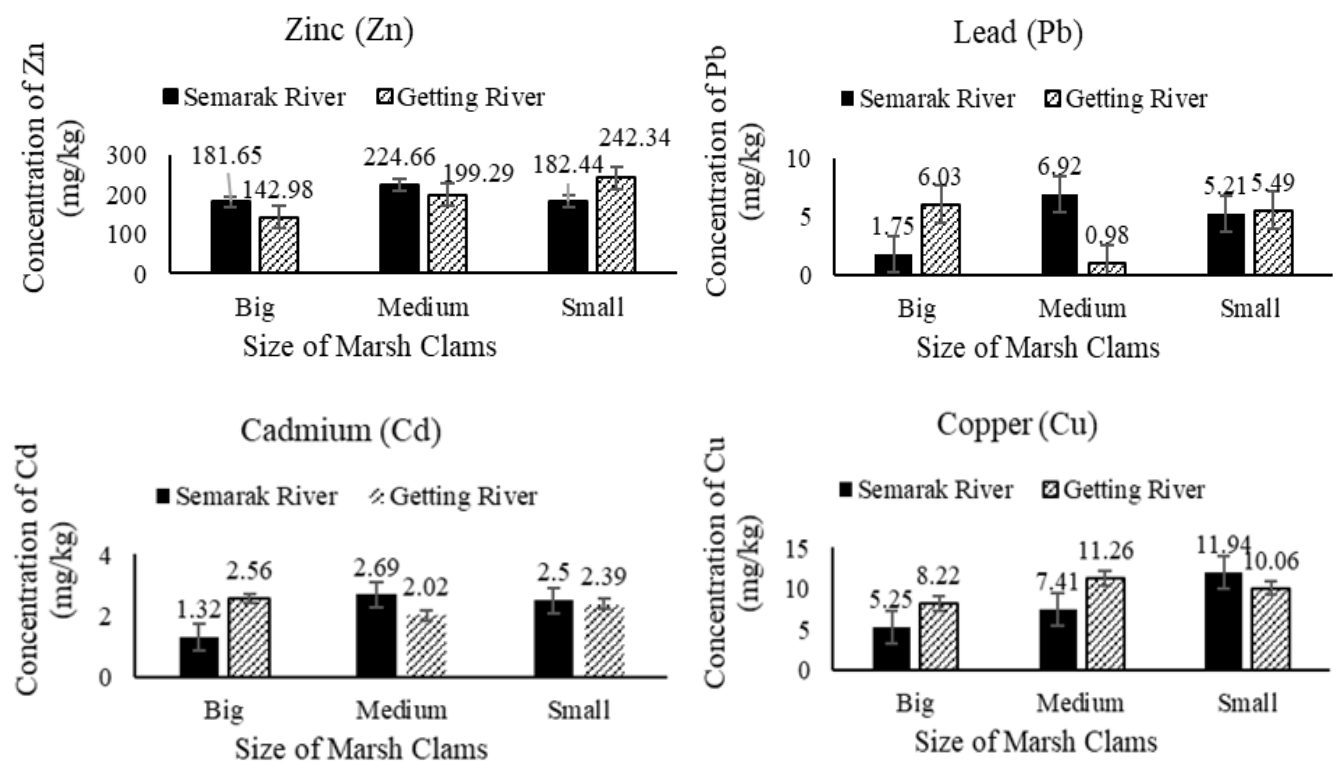

Figure 3 Variation between sizes of marsh clams and concentrations of heavy metals $(\mathrm{Zn}, \mathrm{Cd}, \mathrm{Pb}$ and $\mathrm{Cu})$ in the Semarak and the Geting River, Kelantan.

Trace metal concentrations in clams depend on geographical, temporal, and biological factors [15]. Seasonal intense clam fishing is carried out at the Genting River and the Semarak River during the onset of rain in December. During this season there is considerable run-off from metal mining areas and from human activities. For example, the elevated concentrations of metals in the clams might originate partly from surface run-off in the Semarak River at Tok Bali, Kelantan. These findings tally with Tunisia, which has higher concentrations of heavy metals in clams during higher rainfall periods and in the period of most intense fishing activities [16].

In addition, the higher concentrations of heavy metals were mostly found in the small and medium sizes of marsh clams. This is because small shells have the ability to accumulate greater amounts of metals compared to big shells [23]. Allegedly, the bigger size of shells possesses a better ability to eliminate heavy metals. The rate of the metabolic process starts to slow down when it reaches the big-size stage. Therefore, the ability to accumulate metals also decreases when the marsh clam sizes are larger. Thus, the metal concentrations in the large-sized species were determined to be lower than that of the medium and small sizes. However, based on this study, the concentrations of metals in the samples was not directly proportionate to the sizes of the marsh clams.

The relationships between moisture content and the length of marsh clams were determined by using a regression test, as presented in Figure 4, and Pearson's correlation test. Subsamples of small, medium, and big individuals were distinguished with regard to size frequencies and shell characteristics. According to Figure 4, the moisture content of the marsh clams showed positive correlation with the length of the marsh clams, which indicated the size of marsh clams might influence the moisture content, especially for big and medium sizes. Based on Pearson's correlation, using a 2 tailed test, the results of the big size showed $r=0.73, p<0.05$ and for the medium size $r=0.81, p<0.05$ supported the influences of marsh clams size for water content, especially for the small and medium sizes. The higher moisture contents mean that marsh clams are sensitive to microbial spoilage, as well as meaning that the quality of marsh clams for longer preservation time will decrease the oxidative degradation of polyunsaturated fatty acids [24]. 
Moisture Content VS Length

(Big Size)

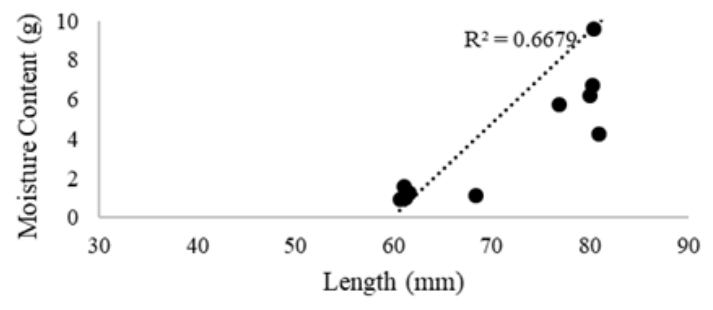

Moisture Content VS Length (Medium Size)

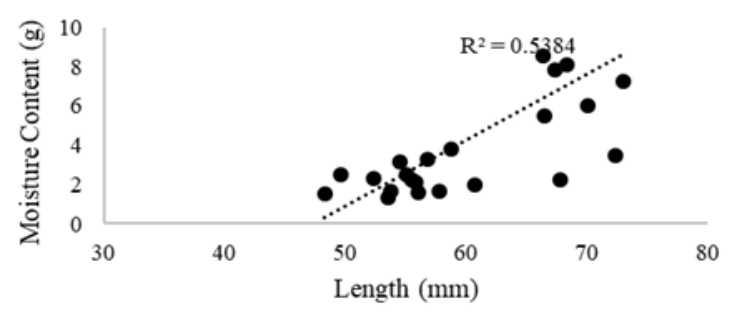

Moisture Content VS Length (Small Size)

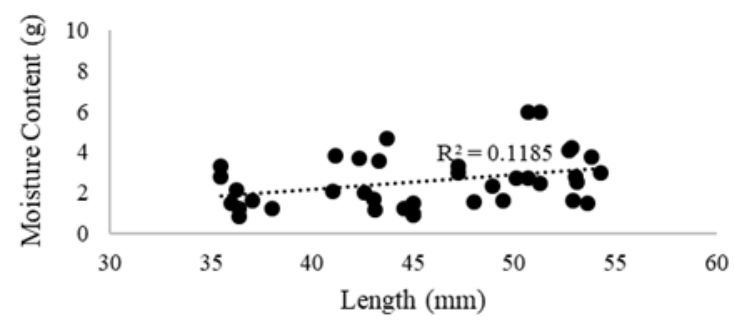

Figure 4 Correlation of moisture content and length of marsh clams in the Getting River and the Semarak River.

\section{River}

Pollution levels of Polymesoda expansa at the industrial and sand mining areas of Kelantan

In developed countries, the limits of heavy metal concentrations in aquatic organism have already been set, in order to safeguard public health. Similarly, the Malaysian government has also set the maximum limits of contaminations for $\mathrm{Zn}, \mathrm{Pb}, \mathrm{Cd}$ and $\mathrm{Cu}$ based on the permissible limits recommended by the Malaysia Food Act, at 100.0, 2.0, 1.0 and 30.0 in the units of $\mathrm{mg} / \mathrm{kg}$, respectively [25]. In this study, $\mathrm{Zn}, \mathrm{Pb}, \mathrm{Cd}$, and $\mathrm{Cu}$ concentrations were not only compared with the permissible limits set by the Malaysia Food Regulation but also the FAO/WHO, at 150.0, 0.5, 0.2 and 10.0 in the units of $\mathrm{mg} / \mathrm{kg}$ respectively; the permissible limits set by the Ministry of Public Health of Thailand (MPHT) for Zn and $\mathrm{Cd}$ at 2.0 and 1.0 in the units of $\mathrm{mg} / \mathrm{kg}$, respectively; and the Food and Drug Administration of the United States (USFDA) for $\mathrm{Zn}, \mathrm{Pb}$, and $\mathrm{Cd}$ at $1.7,10.0$ and 3.7 in the units of $\mathrm{mg} / \mathrm{kg}$, respectively [26].

Based on Figure 5, only $\mathrm{Cu}$ concentrations in the marsh clams from the Semarak River at Tok Bali and the Geting River at Tumpat did not exceed the safety limit, of $30.0 \mathrm{mg} / \mathrm{kg}$. The concentrations of $\mathrm{Zn}, \mathrm{Pb}$ and $\mathrm{Cd}$ in the marsh clams from both the sites exceeded the permissible limits set by the Malaysia Food Regulation. The results were also compared with the regulations of other countries, such as with the Ministry of Public Health of Thailand (MPHT) and the Food and Drug Administration of the United States (USFDA). The results showed that only the concentrations of $\mathrm{Cu}$ were lower than the endorsed guidelines set by the Malaysia Food Regulation. The concentrations of $\mathrm{Cd}$ in the marsh clams from both places exceeded the permissible limits of the Malaysia Food Regulation, but the value did not exceed the safety limit from the USFDA, which by that standard meant the clams were safe for human consumption. 


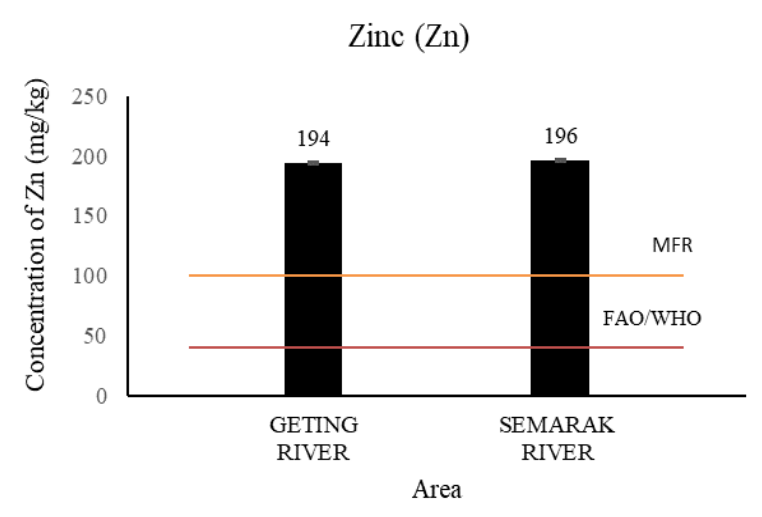

Cadmium (Cd)

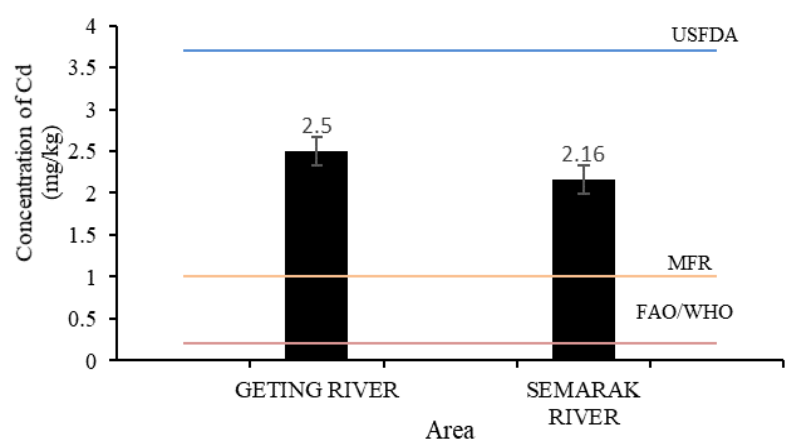

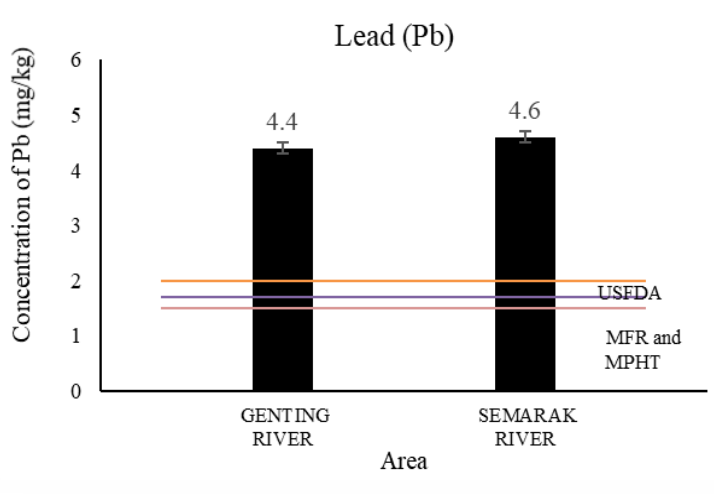

Copper $(\mathrm{Cu})$

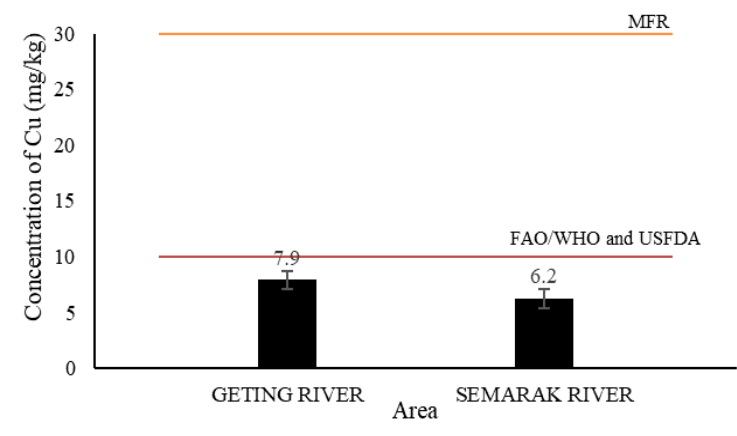

Figure $5 \mathrm{Zn}, \mathrm{Pb}, \mathrm{Cd}$ and $\mathrm{Cu}$ concentrations in marsh clams with permissible limits from the Malaysia Food Safety and Food Regulation (MFR), the Food and Agricultural Organization (FAO), the World Health Organization (WHO), the Ministry of Public Health Thailand (MPHT), and the Food and Drug Administration of the United States (USFDA).

\section{Conclusions}

This study proved that heavy metals can be accumulated in the tissues of marsh clams. Metals transferred through aquatic food webs to marsh clams and humans are of environmental and human health concern. The concentrations of $\mathrm{Zn}, \mathrm{Pb}$ and $\mathrm{Cd}$ in the marsh clams exceeded the maximum permissible levels as recommended by the Malaysia Food Regulation and the FAO/WHO. Therefore, precautions should be taken by humans during the consumption of these marsh clams, because long term consumption of these heavy metals via marsh clams could severely damage human health. In addition, it is very important to observe or monitor the concentrations of heavy metals in the Kelantan river near to industrial and sand mining areas in order to reduce the risk to human health.

\section{Acknowledgements}

The authors wish to express their gratitude to the Faculty of Bioengineering and Technology teams for their invaluable assistance and for providing the facilities to carry out the research. Thanks to UMK for providing a grant, code number R/SGJP/A1300/01684A/004/2019/000682.

\section{References}

[1] AH Yusoff, AA Sabuti and CAR Mohamed. Natural uranium and thorium isotopes in sediment cores off Malaysian ports. Ocean Sci. J. 2015; 50, 403-12.

[2] H Shaari, M Azmi, K Sultan, L. Bidai and Y Mohamad. Spatial distribution of selected heavy metals in surface sediment of the EEZ of the east coast of Peninsular Malaysia. Int. J. Oceanogr. 2015; 2015, 618074. 
[3] TR Chiu, MF Khan, MT Latif, MSM Nadzir, HHA Hamid, H Yusoff and MM Ali. Distribution of Polycyclic Aromatic Hydrocarbons (PAHs) in surface sediments of Langkawi Island, Malaysia. Sains Malays. 2018; 47, 871-82.

[4] NHA Razak, SM Praveena, AZ Aris and Z Hashim. Quality of Kelantan drinking water and knowledge, attitude and practice among the population of Pasir Mas, Malaysia. Publ. Health 2016; 131, 103-11.

[5] PY Tan and H Rohasliney. Status of water quality subject to sand mining in the Kelantan River, Kelantan. Trop. Life Sci. Res. 2013; 24, 19-34.

[6] BY Kamaruzzaman, MSM Zahir, BA John, KCA Jalal, S Shahbudin, SM Al-Barwani and JS Goddard. Bioaccumulation of some metals by Green Mussel Perna viridis (Linnaeus, 1758) from Pekan, Pahang, Malaysia. Int. J. Biol. Chem. 2011; 5, 54-60.

[7] B Ndome, UB Ekaluo, and FE Asuquo. Comparative bioaccumulation of heavy metals (Fe, Mn, Zn, $\mathrm{Cu}, \mathrm{Cd}$ and $\mathrm{Cr}$ ) by some edible aquatic mollusk from the Atlantic coastline of South Eastern Nigeria. World J. Fish Mar. Sci. 2010; 2, 317-21.

[8] H Beldi, F Gimbert, S Maas, R Scheiler and N Soltani. Seasonal variations of $\mathrm{Cd}, \mathrm{Cu}, \mathrm{Pb}$ and $\mathrm{Zn}$ in the edible mollusc Donax trunculus (Mollusca, Bivalvia) from the gulf of Annaba, Algeria. Afr. J. Agr. Res. 2006; 1, 085-90.

[9] LJ De Astudillo, IC Yen and I Bekele. Heavy metals in sediments, mussels and oysters from Trinidad and Venezuela. Int. J. Trop. Biol. 2005; 53, 41-53.

[10] L Lias, T Jamil and SN Aliaa. Preliminary study on heavy metal concentration in the marine bivalves Marcia marmorata species and sediments collected from the coastal area of Kuala Perlis, North of Malaysia. IOSR J. Appl. Chem. 2013; 4, 48-54.

[11] CK Wong, RY Cheung and MH Wong. Heavy metal concentrations in green-lipped mussels collected from Tolo Harbour and markets in Hong Kong and Shenzhen. Environ. Pollut. 2000; 109, 165-71.

[12] PS Rainbow. Trace metal concentrations in aquatic invertebrates: Why and so what? Environ. Pollut. 2002; 120, 497-507.

[13] ZQ Fang, RY Cheung and MH Wong. Heavy metals in oysters, mussels and clams collected from coastal sites along the Pearl River Delta, South China. J. Environ. Sci. (China). 2003; 15, 9-24.

[14] L Li, B Zheng and L Liu. Biomonitoring and bioindicators used for river ecosystems: Definitions, approaches and trends. Proc. Environ. Sci. 2015; 2, 1510-24.

[15] D Adjei-Boateng, KA Obirikorang and S Amisah. Bioaccumulation of heavy metals in the tissue of the clam Galatea paradoxa and sediments from the volta estuary, Ghana. Int. J. Environ. Res. 2010; 4, 533-40.

[16] AG Ebadi and H Hisoriev. The prevalence of heavy metals in Cladophora glomerata L. from Farahabad Region of Caspian Sea - Iran. Toxicol. Environ. Chem. 2017; 99, 883-91.

[17] AHA Dabwan and M Taufiq. Bivalves as bio-indicators for heavy metals detection in Kuala Kemaman, Terengganu, Malaysia. Indian J. Sci. Tech. 2016; 9, 1-6.

[18] MY Sabarina, H Zaini, NAN Ariffin and B Mohd. Cadmium, Chromium, Copper, Lead, Ferum and Zinc levels in cockles (Anadara granosa) from Kuala Selangor Malaysia. Malays. J. Anal. Sci. 2014; 18, 514-21.

[19] KJ Elnabris, SK Muzyed and NM El-Ashgar. Heavy metal concentrations in some commercially important fishes and their contribution to heavy metals exposure in Palestinian people of Gaza Strip (Palestine). J. Assoc. Arab Univ. Basic Appl. Sci. 2013; 13, 44-51.

[20] R Hashim, TH Song, NZM Muslim and TP Yen. Determination of heavy metal levels in fishes from the lower reach of the Kelantan River, Kelantan, Malaysia. Trop. Life Sci. Res. 2014; 25, 21-39.

[21] AO Bazzi. Heavy metals in seawater, sediments and marine organisms in the Gulf of Chabahar, Oman Sea. J. Oceanogr. Mar. Sci. 2014; 5, 20-9.

[22] CK Yap and AM Azri. Heavy metal concentration (Cd, Cu, Fe, Ni, Pb and Zn) in clam, Polymesoda erosa collected from intertidal area of Tok Bali and Kuala Kemasin, Kelantan. Malaysian Appl. Biol. J. 2009; 38, 81-4.

[23] S Rudiyanti. Bioconcentration of blood shells (Anadara granosa) against heavy metals Cd are contained in the maintenance media derived from Kaliwungu waters, Kendal. Res. J. Univ. Diponegoro Semarang 2017; 2017, 12.

[24] N Diani, B Dwi, J Ransangan, DJ Denil, and TK Soon. Heavy metals in marsh clam (Polymesoda expansa) and green mussel (Perna viridis) along the northwest coast of Sabah, Malaysia. Borneo J. Mar. Sci. Aquac. 2017; 1, 25-32. 
[25] A Philip. Food safety in Malaysia. Jpn. Med. Assoc. J. 2015; 58, 180-4.

[26] USFDA (Food \& Drug Administration of the United States). US Food and Drug Administration Shellfish Sanitation Branch. Washington DC, 1990. 